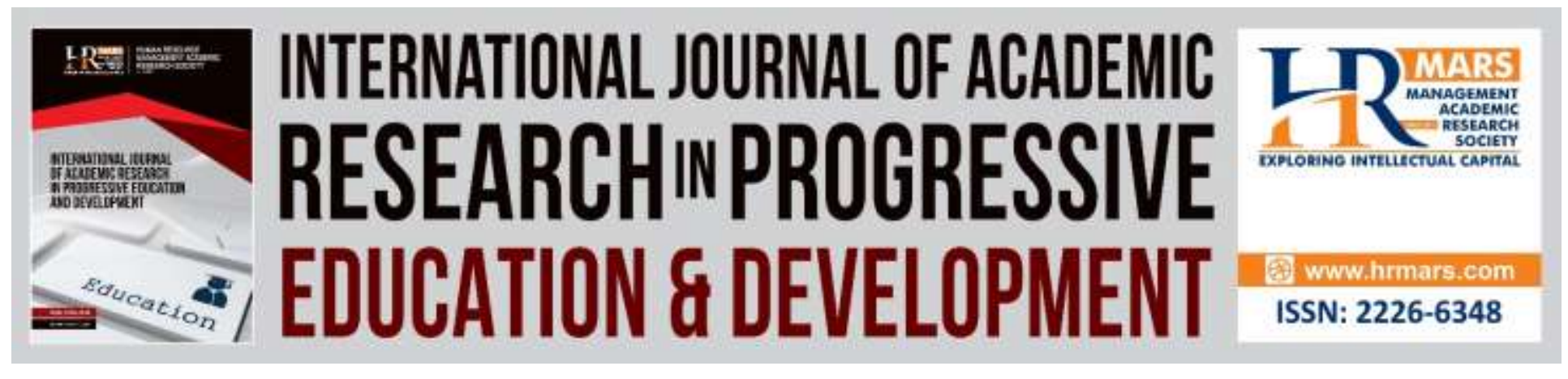

\title{
'Push-Pull' Model of Lifelong Learning in Perak and Selangor
}

\author{
Emilda Hashim, Norimah Rambeli@ Ramli, Maryam Mahdinezhad, Asmawi \\ Hashim, Norasibah Abdul Jalil
}

To Link this Article: http://dx.doi.org/10.6007/IJARPED/v8-i4/6431

DOI: 10.6007/IJARPED/v8-i4/6431

Received: 28 July 2019, Revised: 16 August 2019, Accepted: 02 September 2019

Published Online: 11 September, 2019

In-Text Citation: (Hashim, Ramli, Mahdinezhad, Hashim, \& Jalil, 2019)V

To Cite this Article: Hashim, E., Ramli, N. R., Mahdinezhad, M., Hashim, A., \& Jalil, N. A. (2019). 'Push-Pull' Model of Lifelong Learning in Perak and Selangor. International Journal of Academic Research in Progressive Education and Development, 8(4), 12-21.

Copyright: () 2019 The Author(s)

Published by Human Resource Management Academic Research Society (www.hrmars.com)

This article is published under the Creative Commons Attribution (CC BY 4.0) license. Anyone may reproduce, distribute, translate and create derivative works of this article (for both commercial and non-commercial purposes), subject to full attribution to the original publication and authors. The full terms of this license may be seen at: http://creativecommons.org/licences/by/4.0/legalcode

Vol. 8(4) 2019, Pg. 12- 21

http://hrmars.com/index.php/pages/detail/IJARPED

JOURNAL HOMEPAGE

Full Terms \& Conditions of access and use can be found at http://hrmars.com/index.php/pages/detail/publication-ethics 


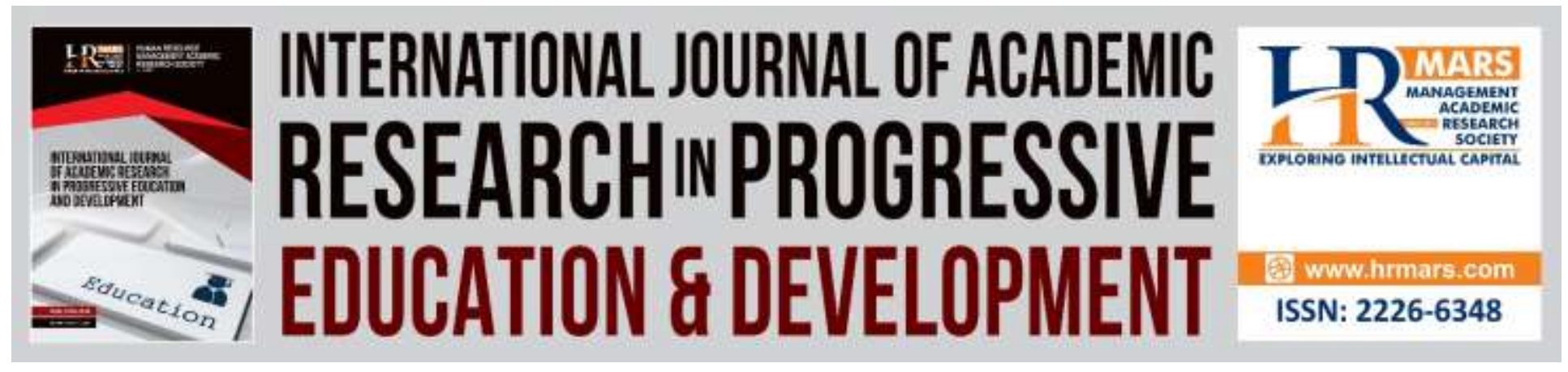

\title{
'Push-Pull' Model of Lifelong Learning in Perak and Selangor
}

\author{
Emilda Hashim, Norimah Rambeli@ Ramli, Maryam \\ Mahdinezhad, Asmawi Hashim, Norasibah Abdul Jalil \\ Sultan Idris Education University (UPSI), Malaysia
}

\begin{abstract}
Adapting to the needs of students, working adult learners at local, public and private, universities in Malaysia enjoy greater autonomy in pursuing their education. Therefore, this study aims to identify 'push-pull' factors that determine working adult learners' choice to pursue their studies. Additionally, this study also figures out the relationship between 'push-pull' factors in motivating students to further their academic studies. 200 questionnaires were distributed to working adult students pursuing part-time programs in public and private universities around Selangor and Perak. The 'push-pull' model was used in this study to identify which factors were the most influential in determining adult students enrolling in the study. Multiple regression analysis will also be used in this study to see the relationship between push-pull model and the tendency of students to choose to pursue their studies. For these purposes, statistical and econometrics analyses were used in this study. The results claimed that both push and pull factors were considered to be important when making decision to return to learning environment among working adults. Education and human resource development are closely intertwined and key to increase national competitiveness and enhance the country's economy.
\end{abstract}

Keywords: Push-Pull Model, Lifelong Learning (LI), Economics Education, Econometrics, Malaysia

\section{Introduction}

Education is seen as one of the major components of human capital. In addition to increasing the productivity of the workforce, education has a spillover effect, which education benefits the people who receive it as well as benefit the community. Education is a sure investment for the production of highly skilled human capital (Yogish, 2006; Alkhimenko, O. N., et. al., 2014). The Icheon Declaration, Article 10, UNESCO states that it will remain committed to ensure lifelong learning (LL) opportunities for all, in all situations and at all levels of education (World Education Forum, 2015; Ahmed, Isa, Majid, Zin, \& Amin, (2017). In line with this, the Ministry of Higher Education Malaysia has made LLL one of the main agendas in its Education Development Plan (2015-2025) on the importance of education in promoting lifelong learning 
(LL). Laal (2011) claims that lifelong learning is a lifelong development of skills and knowledge, which is achieved through the experience of a lifetime.

Adapted to the needs of students, part-time students at local, public and private universities enjoy greater autonomy and autonomy in determining their learning. Kimberley, et. al. (2016) and Altzinger et. al, (2015) explore the importance of knowledge in various aspects at an older age. The extension of adult student learning is also seen as more flexible than traditional campus programs, comprising full-time students on campus. Flexibility is viewed from the perspective of no age limit or academic inclusion criteria and which uses flexible scheduling, curriculum, and teaching methods (Leach \& Webb, 1993). Furthermore, Firat (2017) reveals the importance of lifelong learning. He finds that Turkish students choose distance education not because of geographical restrictions, family-related issues or economic problems, but for reasons such as their involvement in their professions, to improve their knowledge and to seek better employment opportunities and positions.

It is also supported by Mohamad and Razali (2009); Ahmed, Umrani, Qureshi, \& Samad, (2018) who discover that employers are hiring new employees with a wide range of academic skills, group work skills, and personal management skills with leadership and knowledge quality. Therefore, awareness of the importance of continually improving skills and knowledge should be available to every individual, especially those in the workforce. This is to ensure that the skills and knowledge available are up to date as required by the employer.

Other literature reviews also confirm the popular view that more mature students are pursuing a part-time university education. (Holmberg, 1995; Jevons, 1990). In addition, Wallace (2007) shows that the population of part-time students has shifted to younger students, neighborhoods, and the full-time course load that drives students to pursue part-time studies. He also finds that the most important obstacle that drives students to enroll in part-time study is work commitment; while the most important attraction relates to the control of time, place, and learning time. Oliver, et. al. (2017) support the role of disposition and hope on life satisfaction among older adults in attending lifelong learning programs. Moreover, Siivonen (2016); Ahmed, Majid, \& Zin, (2016) points out that the continuous and up-to-date competency and continued success learning is necessary to succeed in their careers.

Therefore, we need to ascertain whether the 'push-pull' factors lead these students to choose these modalities. In this regard, the study of 'push-pull' factors in lifelong learning among working adults is important and necessary to ensure that the actions taken by the government so far are accurate and in line with the huge yearly budget allocated for education. Thus, this study aims to identify 'push-pull' factors that determine working adult learners' choice to pursue their studies. Finally, this study also figures out the relationship between 'push-pull' factors in motivating students to further their academic studies.

The research conceptual framework of 'push-pull' model in lifelong learning is portrayed in Figure 1. 


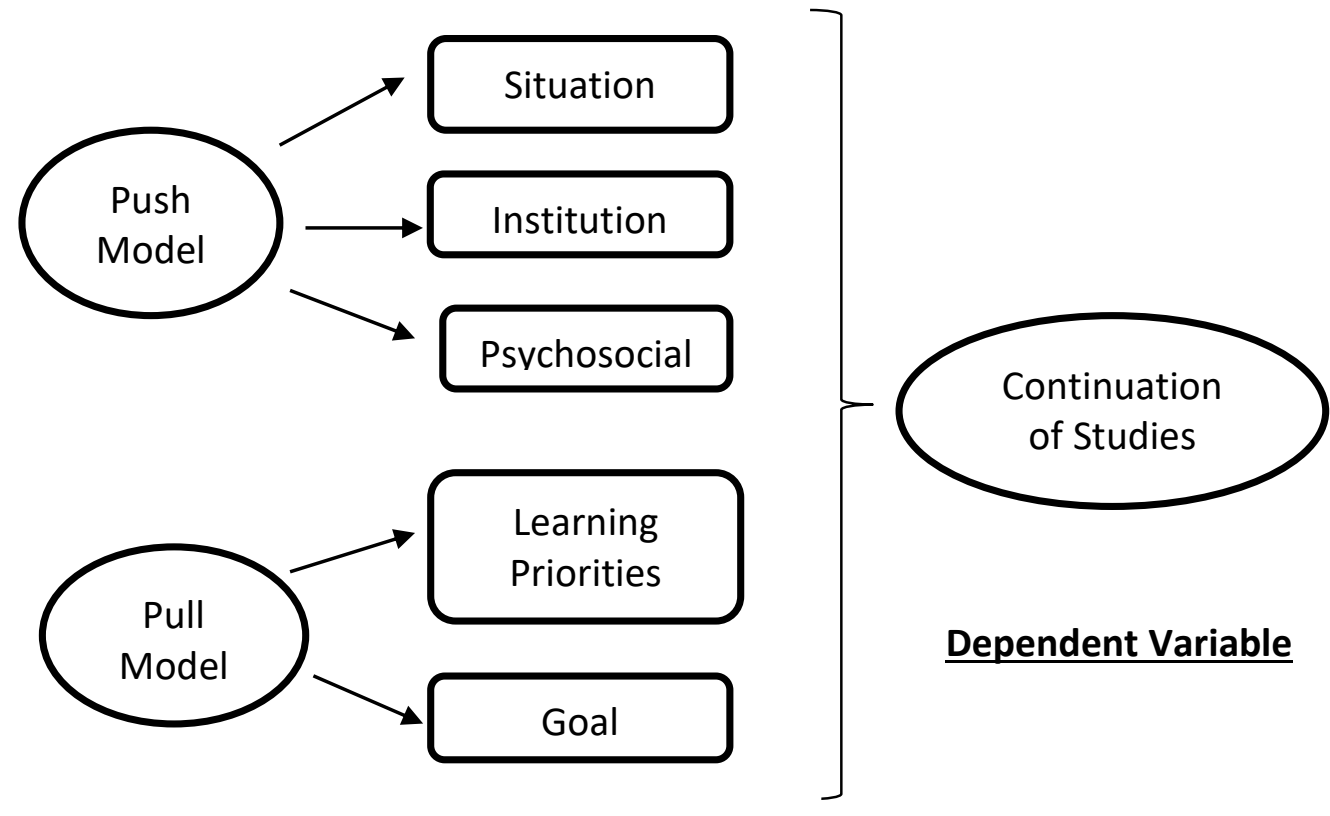

Independent Variable

Figure 1 Research Conceptual Framework of 'Push-Pull' Model in Lifelong Learning

\section{Methodology}

This study was conducted by using the primary data method through survey studies distributed around Perak and Selangor. The questionnaires were adapted from Wallace (2007). The respondents consisted of part-time working adult students studying in public and private universities in those two states. Out of 200 survey forms distributed, we managed to analyzed 125 forms, which were completely filled out by the respondents.

Push model (response to obstruction) and pull model (attraction of learning) were used in this study to identify which factors were most influential in determining working adults to enroll in the academic studies. Factor analysis will then be used to answer the 'push-pull' model. In addition, differences in demographic and socioeconomic composition are also expected to be identified as contributors to the continuation of studies at public and private universities among working adults. For these purposes, statistical analyses were used to obtain the results. On the other hand, econometric analysis examined the relationship between 'push-pull' model and the tendency of students to choose to pursue their studies.

\section{General Function}

The general equation of the regression model becomes,

$Y_{t}=\alpha_{0}+\alpha_{i}+\varepsilon_{t}$

whereby,

$\alpha_{0}=$ constant

$\alpha_{i}=$ Coeficient with (i=1,2,3, 4 dan 5) 
INTERNATIONAL JOURNAL OF ACADEMIC RESEARCH IN PROGRESSIVE EDUCATION AND DEVELOPMENT

Vol. 8, No. 4, 2019, E-ISSN: 2226-6348 @ 2019 HRMARS

$\varepsilon_{\mathrm{i}}=$ error term

$Y_{i}=$ pursue studies

'Push-Pull' Model Function

Adapted from Wallace (2007), the general function of the multiple regression becomes,

$Y_{i}=\alpha_{0}+S_{1}+S_{2}+S_{3}+S_{4}+I_{5}+I_{6}+I_{7}+P_{8}+L_{9}+L_{10}+L_{11}+L_{12}+L_{13}+L_{14}+L_{15}+G_{16}+G_{17}+G_{18}+G_{19}$

$+\mathrm{G}_{20}+\mathrm{G}_{21}+\mathrm{G}_{22}+\varepsilon_{\mathrm{i}}$

whereby,

$\alpha_{0} \quad=$ constant

$\varepsilon_{\mathrm{i}} \quad=$ error term

$Y_{i} \quad=$ pursue studies

$\mathrm{S}_{\mathrm{i},} \mathrm{I}_{\mathrm{i}}, \mathrm{P}_{\mathrm{i}}=$ push factor (situation, institution and psychosocial)

$\mathrm{L}_{\mathrm{i}}, \mathrm{G}_{\mathrm{i}}=$ pull factor (learning priorities and goal)

\section{Result Findings}

In demographic composition, the results revealed that gender and race aspects were not significant in deciding whether working adult students enrolled and continued their studies. Meanwhile, in socio-economic aspects, highest education qualification and current working sectors in those working adults were significant in pursuing their education. In contrast, courses of study, fields of study and occupations were not significant determinants for working adults to further their studies.

\section{Table 1 'Push-Pull' Factor Analysis In Determining Working Adults Choose to Pursue Their Studies}

\begin{tabular}{|ll|}
\hline \multicolumn{1}{|c|}{ Item } & Min \\
\hline Push Factor & 3.09 \\
\hline Situation & 2.36 \\
\hline Institution & 3.02 \\
\hline Psychosocial \\
\hline Pull Factor \\
\hline Learning Priorities & 3.25 \\
\hline Goal & 3.69 \\
\hline
\end{tabular}

Table 1 showed factor analysis of 'push-pull' model that determine working adults to continue their studies at government and private institutions around Perak and Selangor. There were five categories that were important in 'push-pull' model, namely, situation, institution, psychosocial under push factors, while learning priorities and goal priorities felt under pull factors.

Based on the results, pull factor exceeded push factor in this factor analysis, through which the goal category, had the highest overall mean score of 3.69. In addition, learning 
INTERNATIONAL JOURNAL OF ACADEMIC RESEARCH IN PROGRESSIVE EDUCATION AND DEVELOPMENT

Vol. 8, No. 4, 2019, E-ISSN: 2226-6348 @ 2019 HRMARS

priorities, a pull factor, followed behind with second highest mean score of 3.25. This specified that the main factor for working adult to pursue their studies was due to the goals and learning priorities of the adult learners. Meanwhile, push factors, specifically, situation, institution and psychosocial had moderate mean scores in influencing them to further their studies at government and private institutions, with mean score of 3.09, 2.36 and 3.02, respectively.

Table 2 'Push-Pull' Correlation of Working Adult Students

\begin{tabular}{|ll|l|l|l|l|l|}
\hline & & mean_S & mean_I & mean_P & mean_L & mean_G \\
\hline mean_S & Pearson Correlation & 1 & $.378^{* *}$ & $.364^{* *}$ & $.231^{* *}$ & $.245^{* *}$ \\
& Sig. (1-tailed) & & .000 & .000 & .005 & .003 \\
& N & 125 & 125 & 125 & 125 & 125 \\
\hline mean_I & Pearson Correlation & $.378^{* *}$ & 1 & $.265^{* *}$ & .077 & -.024 \\
& Sig. (1-tailed) & .000 & & .001 & .198 & .396 \\
& N & 125 & 125 & 125 & 125 & 125 \\
\hline mean_P & Pearson Correlation & $.364^{* *}$ & $.265^{* *}$ & 1 & $.314^{* *}$ & $.364^{* *}$ \\
& Sig. (1-tailed) & .000 & .001 & & .000 & .000 \\
& N & 125 & 125 & 125 & 125 & 125 \\
\hline mean_L & Pearson Correlation & $.231^{* *}$ & .077 & $.314^{* *}$ & 1 & $.583^{* *}$ \\
& Sig. (1-tailed) & .005 & .198 & .000 & & .000 \\
N & 125 & 125 & 125 & 125 & 125 \\
\hline mean_G & Pearson Correlation & $.245^{* *}$ & -.024 & $.364^{* *}$ & $.583^{* *}$ & 1 \\
& Sig. (1-tailed) & .003 & .396 & .000 & .000 & \\
N & 125 & 125 & 125 & 125 & 125 \\
\hline
\end{tabular}

* 0.01 level of significance

Table 2 indicated the degree of strength of the relationship between 'push-pull' variables in continuing their education. The outcome pointed out that all variables did not have high correlation between variables. To illustrate, learning priorities and goals were moderately and positively correlated with $r=0.583$. Besides, situation and institutions, situation and psychosocial, as well as psychosocial and learning priorities, also had moderate and positive relationships with magnitude of $0.378,0.364,0.314$, respectively. In contrast, the results also established the fact that the other variables were either weak or no relationship. Since none of the coefficient of the correlation were higher than 0.7 , then there were no case of multicollinearity. The data also passed all other assumptions to proceed with regression analysis. 
INTERNATIONAL JOURNAL OF ACADEMIC RESEARCH IN PROGRESSIVE EDUCATION AND DEVELOPMENT

Vol. 8, No. 4, 2019, E-ISSN: 2226-6348 @ 2019 HRMARS

\section{'Push-Pull' Model}

$Y_{t}=\alpha_{0}+S_{1}+S_{2}+S_{3}+S_{4}+I_{5}+I_{6}+I_{7}+P_{8}+L_{9}+L_{10}+L_{11}+L_{12}+L_{13}+L_{14}+L_{15}+G_{16}+G_{17}+G_{18}$

$+\mathrm{G}_{19}+\mathrm{G}_{20}+\mathrm{G}_{21}+\mathrm{G}_{22}+\varepsilon_{\mathrm{t}}$

Table 3 Relationships between Push-Pull Variables and Pursue Studies

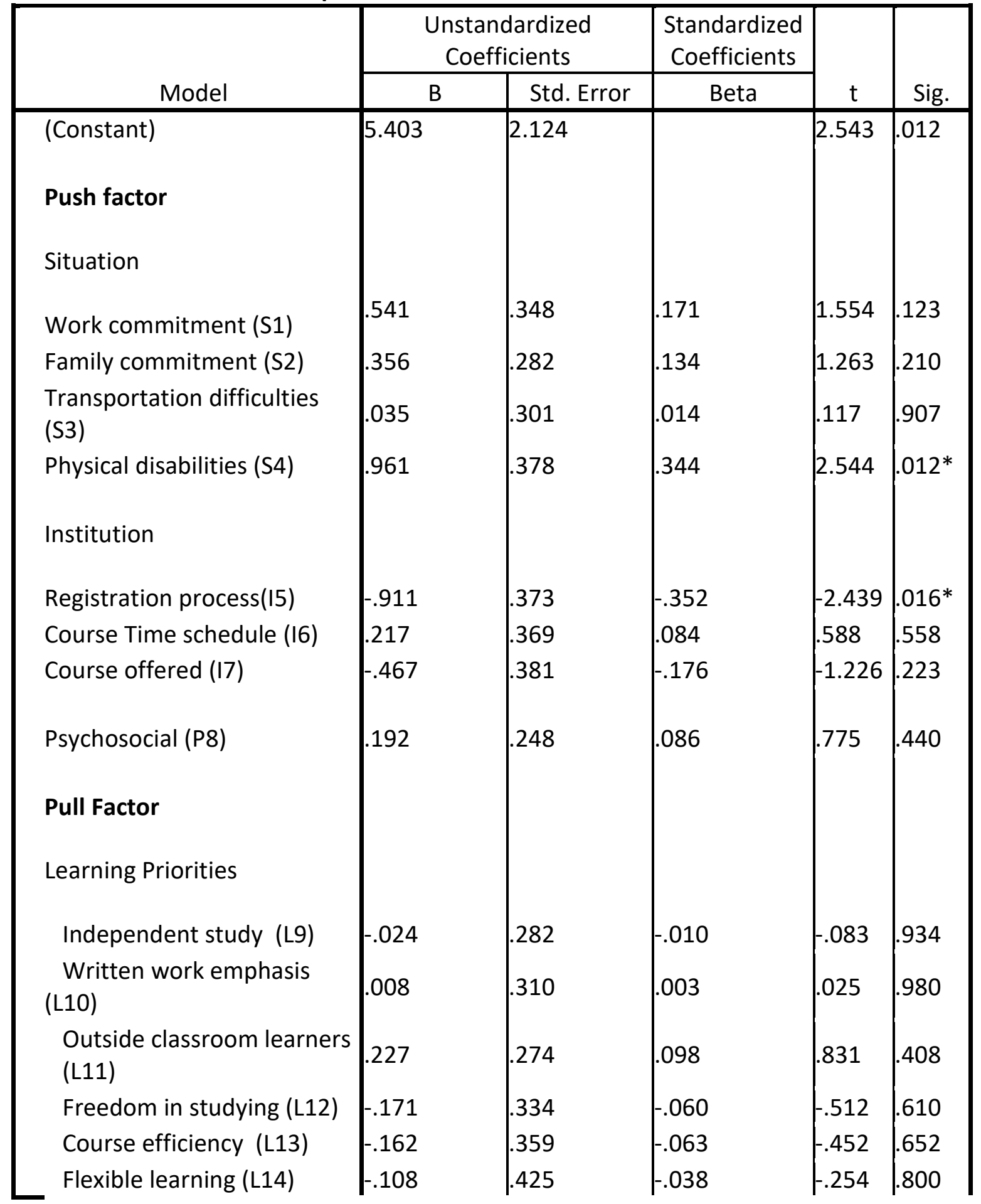


Vol. 8, No. 4, 2019, E-ISSN: 2226-6348 @ 2019 HRMARS

\begin{tabular}{|l|l|l|l|l|l|}
\hline $\begin{array}{l}\text { Detailed assignment } \\
\text { feedback (L15) }\end{array}$ & -.186 & .480 & -.061 & -.388 & .699 \\
Goal & & & & & \\
Knowledge driven (G16) & .102 & .447 & .037 & .227 & .821 \\
Excellent grades (G17) & .275 & .421 & .097 & .652 & .516 \\
Free time (G18) & .349 & .389 & .127 & .897 & .372 \\
Attraction to learning (G19) & -1.194 & .512 & -.372 & -2.334 & $.022 *$ \\
Challenging (G20) & .084 & .279 & .033 & .303 & .763 \\
Response to own needs & .161 & .447 & .052 & .360 & .720 \\
(G21) & .043 & .430 & .014 & .099 & .921 \\
Inclusive package (G22)
\end{tabular}

* 0.05 significance value

Table 3 demonstrated the regression result of the analysis of the 'push-pull' factors that caused working adult students to further their studies. From the table, only three outstanding factors had significant relationships that drove working adults to pursue their studies. We could see that the statistical values, $0.012,0.016$ and 0.022 , which were below 0.05 significance level, respectively. Since these three variables were below 95\% confidence level, we rejected null hypothesis. This condition meant that these three factors were significant in determining working adults' decision to further their studies. Unfortunately, the rest of the variables were deemed to be insignificant factors whereby we had to accept $\mathrm{H}_{0}$, meaning that there were no significant relationship between these variables and working adults' decision to pursue their studies.

Therefore, two push factors, physical disabilities of adult students $\left(\mathrm{S}_{4}\right)$ and easier registration process $\left(I_{5}\right)$ under each category, situation and institution, respectively, were important determinants for working adults to make such decision. Furthermore, attraction to learning, which felt under goal category in pull model, was also vital for these working adults in pursuing their education. It was considered to be one of the significant factors that pull working adults to the academic studies. Despite all that, the remaining 'push-pull' factors had no significant impacts on working adults to go back to the learning environment.

\section{Conclusion}

In a nutshell, this study concluded that goal was essential in deciding whether working adults should pursue their studies or not. Other than that, in one aspect of each category in 'pushpull' model, particularly, situation, institution and goal were significant contributors to such vital decision. Hence, both push and pull factors were considered to be important, when making decision to return to academic studies among working adults. Lastly, education and human resource development are closely intertwined and key to increase national competitiveness and enhance the country's economy. 
INTERNATIONAL JOURNAL OF ACADEMIC RESEARCH IN PROGRESSIVE EDUCATION AND DEVELOPMENT

Vol. 8, No. 4, 2019, E-ISSN: 2226-6348 @ 2019 HRMARS

\section{Acknowledgement}

This paper is based on the research project entitled Model "Tolakan-Tarikan" Pembelajaran Sepanjang Hayat di Perak dan Selangor. The authors would like to extend their gratitude to the Research Management and Innovation Centre (RMIC), Sultan Idris Education University (UPSI) for the University Research Grants (code: 2017-0257-107-01) that helped fund the research.

\section{Corresponding Author}

Emilda Hashim

Faculty of Management and Economics, Sultan Idris Education Unviersity, Malaysia

Email: emilda@fpe.upsi.edu.my

\section{References}

Ahmed, U., Majid, A. H. A., \& Zin, M. L. M. (2016). HR Moderating HR: Critical link between Developmental HR Practices and work engagement in a Moderated Model. Management Review: An International Journal, 11(2), 4-22.

Ahmed, U., Umrani, W. A., Qureshi, M. A., \& Samad, A. (2018). Examining the links between teachers support, academic efficacy, academic resilience, and student engagement in Bahrain. International Journal of Advanced and Applied Sciences, 5(9), 39-46.

Ahmed, U., Isa, N. M., Majid, A. H. A., Zin, M. L. M., \& Amin, B. M. (2017). Towards understanding work engagement: can HR really buffer HR? Test of a moderated model. International Journal of Economic Research, 14(20), 1-18.

Firat, M. (2017). Turkish Students' Preferences for Distance Education Depending on Financial Circumstances: A large-scale CHAID Analysis, International Review Education, 63:197212.

Holmberg, B. (1995). The evolution of the character and practice of distance education. Open Learning, 10(2), 47-52.

Jevons, F. (1990). Blurring the Boundaries: Parity and Convergence. In R. Garrison \& D. Shale (Eds.), Education at a distance: From issues to practice. Malabar, FL: Robert E. Kreiger.

Laal, M. (2011). Lifelong Learning: What does it mean?. Procedia-Social and Behavioral Sciences. 28. 470-474

Leach, R., \& Webb, R. (1993). Opportunities through open learning. In J. Calder (Ed.), Disaffection and diversity: Overcoming barriers for adult learners (pp. 91-109). London: The Falmer Press.

Malaysia (2015). Pelan Pembangunan Pendidikan Malaysia 2015-2025 (Pendidikan Tinggi). Putrajaya: KPT.

Mohamad, Mohaffyza, M., Razali, C., Munira, C. (2009). Keperluan Pembelajaran Sepanjang Hayat bagi Tenaga Pengajar di Institut Latihan Kemahiran di Malaysia. The 3rd Malaysian Technical Universities Conference on Engineering and Technology (MUCEET2009), 20-22 June 2009, Kuantan, Pahang, 613-623

Siivonen, P. (2016). Becoming an Educable Lifelong Learning Subject: Adult Graduates Transition in Education and Working LIfe. International Journal of lifelong Education. Vol 35, Issue 1, 36-50. https://doi.org/10.1080/02601370.2015.1129365

Wallace, L. (2007). " Changes in the Demographics and Motivations of Distance Education 
INTERNATIONAL JOURNAL OF ACADEMIC RESEARCH IN PROGRESSIVE EDUCATION AND DEVELOPMENT

Vol. 8, No. 4, 2019, E-ISSN: 2226-6348 ๑ 2019 HRMARS

Students". International Journal of E-Learning and Distance Education.Vol 11, No. ,1-31.

World Education Forum (2015). Final Report 2015. Retrieved from

https://unesdoc.unesco.org/ark:/48223/pf0000243724

Yogish, S. N. (2006). Education and Economic Development. Indian Journal of Social

Development, Vol. 6, No.2, pp. 255-270 